\title{
Peran Penyuluh Pertanian terhadap Tingkat Produksi Usahatani Jagung
}

\section{The Agricultural Extension Agent's Role on the Level of Corn Farming Production}

\author{
Novianda Fawaz Khairunnisa*), Zumi Saidah, Hepi Hapsari, Eliana Wulandari
}

Departemen Sosial Ekonomi Pertanian, Universitas Padjadjaran, Jatinangor, Sumedang, 45363, Indonesia

${ }^{*}$ E-mail korespondensi: noviandafawaz@gmail.com

Diterima: 8 Desember 2020 | Disetujui: 25 Mei 2021 | Publikasi Online: 08 Juni 2021

\begin{abstract}
Agricultural extension agent's have a strategic role in helping to increase maize farming production in Nunuk Baru Village, Maja District, Majalengka Regency. Agricultural extension play a role in guiding farmers in managing their farms effectively and efficiently to improve farmer welfare. Nunuk Baru Village is one of the largest maize producing areas in Maja District which is getting more attention in agricultural extension activities. This study aims to identify the role of agricultural extension for maize farmers and to determine the effect of the role of agricultural extension on the level of maize farming production. The research design used is a quantitative approach with a survey method with 80 corn farmers as respondents. The method of data analysis in this study used descriptive analysis using a sematic differential scale and regression analysis. The results of this study indicate that the role of agricultural extension agent's in Nunuk Baru Village, Maja District, Majalengka Regency is categorized as very good in carrying out their duties as a catalyst, communicator, consultant and organizer while as a motivator, educator and facilitator are categorized as good. The role of agricultural extension agent's has no effect on corn farming production in Nunuk Baru Village.
\end{abstract}

Keywordsi: Farmers, maize farming, production, role of extension agent's

\begin{abstract}
ABSTRAK
Penyuluh pertanian memiliki peran strategis dalam membantu meningkatkan produksi usahatani jagung di Desa Nunuk Baru, Kecamatan Maja, Kabupaten Majalengka. Penyuluh pertanian berperan dalam membimbing petani dalam mengelola usahataninya secara efektif dan efisien sehingga dapat meningkatkan kesejahteraan petani. Desa Nunuk Baru merupakan salah satu daerah penghasil jagung terbesar di Kecamatan Maja yang mendapatkan perhatian lebih dalam kegiatan penyuluhan pertanian. Penelitian ini bertujuan untuk mengidentifikasi peran penyuluh pertanian bagi petani jagung dan mengetahui pengaruh peran penyuluh pertanian terhadap tingkat produksi usahatani jagung. Desain penelitian yang digunakan yaitu pendekatan kuantitatif dengan metode survei dengan responden sebanyak 80 petani jagung. Metode analisis data pada penelitian ini menggunakan analisis deskriptif dengan menggunakan skala diferensial sematik dan analisis regresi. Hasil penelitian ini menunjukkan bahwa peran penyuluh dikategorikan sangat baik dalam menjalankan tugasnya sebagai katalisator, komunikator, konsultan dan organisator sedangkan sebagai motivator, edukator dan fasilitator dikategorikan baik. Peran penyuluh pertanian tidak berpengaruh terhadap produksi usahatani jagung.
\end{abstract}

Kata kunci: Peran penyuluh, petani, produksi, usahatani jagung

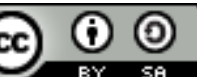

Content from this work may be used under the terms of the Creative Commons Attribution-ShareAlike 4.0 International. Any further distribution of this work must maintain attribution to the author(s) and the title of the work, journal citation and DOI.

Published under Department of Communication and Community Development Science, IPB University and in association with Perhimpunan Ahli Penyuluhan Pembangunan Indonesia.

E-ISSN: 2442-4110 | P-ISSN: 1858-2664 


\section{PENDAHULUAN}

Jagung (Zea mays L.) merupakan salah satu komoditas subsektor tanaman pangan di Indonesia yang memiliki memiliki arti penting baik bagi masyarakat maupun perekonomian Indonesia. Menurut Apriani et al. (2016), komoditas jagung sangat memadai untuk dijadikan makanan pokok sebagai pengganti beras atau dicampurkan dengan beras karena memiliki keunggulan dibanding komoditas pangan lain adalah kandungan gizinya yang hampir sama dengan beras. Selain itu, jagung juga nilai ekonomis karena berfungsi sebagai bahan baku utama bagi pakan ternak dan industri makanan. Mengingat pentingnya peran jagung tersebut, maka perlu untuk memprioritaskan pengembangan produksi jagung dalam negeri dengan meningkatkan efisiensi usahatani (Suryana \& Agustian, 2013).

Jawa Barat merupakan salah satu provinsi penghasil jagung di Indonesia. Luas panen dan produksi jagung di Jawa Barat pada tahun 2017 masing-masing mencapai produksi jagung Provinsi Jawa Barat sebesar 177.296 ha dan 1.424.928 ton (Kementerian Pertanian Republik Indonesia, 2018). Kabupaten Majalengka sebagai salah satu sentra produksi jagung di Jawa Barat memiliki luas panen jagung yang cukup besar yang tersebar di berbagai kecamatan salah satunya yakni Kecamatan Maja. Menurut data Badan Pusat Statistik Kabupaten Majalengka (2018), luas panen, produksi dan produktivitas jagung di Kecamatan Maja Tahun 2017 masing-masing sebesar 3.392 ha, 26.663 ton dan 7,86 ton/ha. Salah satu daerah di Kecamatan Maja yang menghasilkan jagung adalah Desa Nunuk Baru. Desa Nunuk Baru memiliki kondisi topografi yang cocok untuk komoditas jagung. Hal ini menunjukkan bahwa komoditas jagung merupakan komoditas unggul di daerah tersebut yang memiliki potensi cukup besar untuk dikembangkan.

Tinggi rendahnya potensi jagung bergantung besarnya produksi yang dihasilkan dengan luas lahan yang ada. Salah satu faktor yang mempengaruhi tingkat produksi adalah kualitas sumber daya petani dalam mengelola usahataninya. Petani harus mampu mengalokasikan penggunaan faktor-faktor produksi serta teknik budidaya yang efisien dan efektif. Oleh sebab itu, perlu adanya usaha yang dapat meningkatkan kualitas petani di Kecamatan Maja yaitu dengan melakukan melalui pemberdayaan masyarakat petani seperti penyuluhan pertanian. Penyuluhan adalah proses pendidikan yang bertujuan untuk mengubah kesadaran dan perilaku (pengetahuan, sikap, dan keterampilan) manusia ke arah yang lebih baik sehingga mereka menjadi berdaya dan dapat mencapai kehidupan yang lebih baik dan sejahtera (Muljono, 2007).

Penyuluhan pertanian secara teknis dan manajerial dilaksanakan oleh seorang penyuluh yang mempunyai fungsi untuk memberikan pelayanan pendidikan dan informasi yang dibutuhkan petani, sehingga petani dapat berusahatani lebih baik (Rahmawati et al., 2019). M et al. (2019) menyatakan bahwa, peran penyuluh pertanian sangat dibutuhkan untuk membimbing petani dalam meningkatkan keterampilan petani sehingga diharapkan adopsi petani terhadap teknologi pertanian tinggi sehingga dapat meningkatkan hasil produksi petani serta meningkatkan kesejahteraan petani dan keluarganya.

Efektivitas program penyuluhan dapat dicapai apabila minat dan kebutuhan utama masyarakat diprioritaskan dan memperhatikan sumber daya yang ada. Penyuluh pertanian secara umum memiliki peran strategis sebagai jembatan antara pemerintah, petani dan stakeholder eksternal. Penyuluhan pertanian dilaksanakan secara bersama-sama oleh pemerintah melalui penyuluh pertanian, keserasian dan persamaan tujuan antara petani dengan pemerintah tersebut harus jelas sehingga seluruh permasalahan yang dihadapi petani selama ini dapat diselesaikan (Sundari et al., 2015).

Keberhasilan program penyuluhan pertanian sangat dipengaruhi oleh kapasitas tenaga penyuluh dalam menjalankan tugasnya. Kapasitas penyuluh yang rendah akan berdampak pada kegiatan penyuluhan terutama pelaku utama dan pelaku usaha sebagai pengguna jasa penyuluhan (Listiana et al., 2018). Seorang penyuluh pertanian diharapkan mampu menyusun rencana kerja dan melaksanakan penyuluhan berbasis dengan kebutuhan sasarannya yakni petani, kompetensi dan kinerja seorang penyuluh yang baik sangat dibutuhkan untuk mencapai tujuan program penyuluhan (Ardita et al., 2017). Menurut Rahmawati et al. (2019), kinerja penyuluh pertanian yang baik akan berdampak pada perbaikan kinerja petani dalam mengelola usahataninya sehingga dapat meningkatkan produksi usahatani.

Jurnal Penyuluhan | Vol. 17 (02) 2021 | 114 
Penelitian Hernalius et al. (2018), menunjukkan bahwa peran penyuluh pertanian dalam meningkatkan produktivitas padi sawah di Desa Bojongsari, Kecamatan Jampang Kulon, Kabupaten Sukabumi bernilai positif karena berdampak pada perubahan perilaku petani. Penelitian tersebut berfokus pada tingkat keberdayaan pertani melalui penyuluh pertanian terhadap tingkat produktivitsa padi sawah. Penelitian lainnya, Sundari, et al. (2015), tentang peran penyuluh pertanian terhadap peningkatan produksi usahatani di Kabupaten Pontianak. Peran penyuluh tersebut dilihat dari 4 aspek yaitu penyuluh sebagai penasehat, teknisi, penghubung, organisator dan agen pembaharu. Penelitian ini juga menekankan pada peran penyuluh pertanian terutama dalam peningkatan hasil produksi jagung sebagai salah satu bentuk tanggung jawab Dinas Pertanian Kabupaten Majalengka yang memegang peranan penting dalam mewujudkan kondisi ekonomi rumah tangga petani yang layak dan sejahtera. Penelitian ini fokus pada 7 (tujuh) aspek utama peran penyuluh pertanian yang terdiri atas motivator, edukator, fasilitator dan dinamisator (Rahmawati et al., 2019) serta motivator, edukator, katalisator, organisator, komunikator dan juga konsultan (Resicha, 2016). Pada penelitian ini peran penyuluh dilihat dari 7 aspek yaitu sebagai motivator, edukator, katalisator, komunikator, konsultan, fasilitator dan organisator.

Menurut Syahyuti (2014), paradigma penyuluhan yang baru memiliki fungsi tidak hanya untuk mentransfer teknologi agar produksi komoditas meningkat namun lebih dari itu tugas penyuluhan lebih luas karena mencangkup upaya mendidik, mengorganisasikan dan memobilisasi petani. Penyuluhan merupakan proses memberdayakan petani yang dilakukan oleh tenaga penyuluh. Penyuluhan memiliki posisi koheren yakni sebagai sistem pengetahuan yang komprehensif dan tidak terpisah antara penemuan teknologi dan transfernya. Sedangkan petani memiliki posisi sebagai objek dan subjek kegiatan penyuluhan, mengingat petani merupakan aktor atau pelaku utama yang memperoleh manfaat langsung dari kegiatan penyuluhan.

Menurut (Zulfikar et al., 2018), fakta di lapangan menunjukkan bahwa produktivitas hasil pertanian tidak sesuai dengan potensi yang tersedia karena tingkat adopsi teknologi petani yang relatif rendah. Hal tersebut disebabkan respon dan persepsi petani terhadap tenaga penyuluh dalam proses transfer inovasi teknologi yang beragam. Oleh karena itu, perlu dilakukan penelitian tentang penilaian petani terhadap peran penyuluh pertanian di Desa Nunu Baru, Kecamatan Maja, Kabupaten Majalengka. Berdasarkan uraian tersebut, penelitian ini bertujuan untuk mengidentifikasi peran penyuluh pertanian bagi petani jagung serta menganalisis pengaruh peran penyuluh pertanian terhadap tingkat produksi usahatani jagung.

\section{METODE PENELITIAN}

Objek penelitian ini adalah peran penyuluh pertanian dan faktor-faktor yang mempengaruhi produksi usahatani jagung. Penelitian ini dilakukan di Desa Nunuk Baru, Kecamatan Maja, Kabupaten Majalengka Provinsi Jawa Barat. Pemilihan lokasi didasarkan bahwa Desa Nunuk Baru merupakan salah satu daerah dengan produksi jagung terbanyak yang ada di Kecamatan Maja dan daerah yang mendapatkan perhatian lebih dalam kegiatan penyuluhan pertanian. Hal tersebut dikarenakan Desa Nunuk Baru merupakan lokasi pengembangan komoditas jagung khususnya varietas jagung hibrida yang memiliki luas taman dan produktivitas yang cukup berpotensi. Desain penelitian yang digunakan yaitu pendekatan kuantitatif dengan metode survei. Populasi dalam penelitian ini adalah petani jagung yang berjumlah 381 orang. Metode pengambilan sampel dilakukan dengan menggunakan teknik probability sampling dengan metode simple random sampling. Penentuan jumlah sampel dengan menggunakan rumus Slovin dengan taraf signifikansi $\alpha=0,1$ sehingga diperoleh total responden 79,2 (dibulatkan menjadi 80 petani jagung).

Instrumen yang digunakan berupa kuesioner yang terlebih dahulu dilakukan uji validitas dan reliabilitas dengan menggunakan aplikasi STATA versi 14 . Kriteria uji validitas dikatakan valid apabila nilai $r$ hitung > nilai $r$ tabel. Hasil pengujian menunjukkan bahwa dari 21 item pertanyaan memiliki nilai $r$ hitung lebih besar dari $r$ tabel yang artinya item-item pertanyaan dalam kuesioner dinyatakan valid. Uji reliabilitas dalam penelitian ini menggunakan Uji Cronbach Alpha. Indikator dikatakan reliabel ketika 
nilai Cronbach Alpha >0,6. Hasil pengujian menunjukkan bahwa nilai Cronbach Alpha adalah 0,851 yang artinya instrumen reliabel.

Metode analisis data pada penelitian ini menggunakan analisis deskriptif dan analisis regresi linear berganda. Analisis deskriptif dilakukan untuk mengidentifikasi peran penyuluh pertanian terhadap petani jagung di Desa Nunuk Baru. Penilaian kinerja peran penyuluh pertanian dilakukan berdasarkan tujuh peran penyuluh pertanian, yakni: motivator, edukator, katalisator, komunikator, konsultan, fasilitator dan organisator. Setiap peran penyuluh pertanian dinilai berdasarkan 3 indikator yang dapat dilihat pada Tabel 1.

Tabel 1. Indikator Peran Penyuluh Pertanian

\begin{tabular}{|c|c|}
\hline Peran Penyuluh & Indikator \\
\hline \multirow{3}{*}{ Motivator } & Membantu petani dalam mengarahkan usahatani \\
\hline & Mondorong petani dalam mengembangkan usahatani \\
\hline & Mendorong petani untuk menerapkan teknologi dalam usahatani \\
\hline \multirow{3}{*}{ Edukator } & Meningkatkan pengetahuan petani \\
\hline & Melatih keterampilan petani \\
\hline & Memberikan pelatihan menggunakan teknologi \\
\hline \multirow{3}{*}{ Katalisator } & Menyampaikan aspirasi petani \\
\hline & $\begin{array}{l}\text { Menyampaikan peraturan dan kebijakan di sektor pertanian kepada } \\
\text { petani }\end{array}$ \\
\hline & Menghubungkan petani dengan lembaga pemerintahan/swasta \\
\hline \multirow{3}{*}{ Komunikator } & Kemampuan komunikasi yang baik kepada petani \\
\hline & Membantu mempercepat arus informasi petani \\
\hline & Membantu petani dalam mengambil keputusan \\
\hline \multirow{3}{*}{ Konsultan } & Sebagai penasihat petani dalam berusahatani \\
\hline & Membantu petani memecahkan masalah \\
\hline & $\begin{array}{l}\text { Menjelaskan kepada petani mengenai keunggulan dan keuntungan } \\
\text { usahatani }\end{array}$ \\
\hline \multirow{3}{*}{ Fasilitator } & $\begin{array}{l}\text { Memfasilitasi petani dalam kegiatan belajar mengajar/pelatihan untuk } \\
\text { mengembangkan usahatani }\end{array}$ \\
\hline & Memfasilitasi akses petani kepada pihak permodalan \\
\hline & Memfasilitasi petani dalam mengakses pasar \\
\hline \multirow{3}{*}{ Organisator } & $\begin{array}{l}\text { Menumbuhkan dan mengembangkan wahana kerjasama petani dalam } \\
\text { berusahatani }\end{array}$ \\
\hline & Mendorong petani dalam memilih usaha yang menguntungkan \\
\hline & Mengarahkan petani dalam mengordinir kegiatan usahatani \\
\hline
\end{tabular}

Penilaian tersebut akan diberi skor pada setiap variabel yang dihitung menggunakan skala diferensial sematik (Simamora, 2005) yang dapat dilihat pada Tabel 2.

Tabel 2. Kategori Peran Penyuluh Pertanian

\begin{tabular}{ccc}
\hline No. & Interval Kelas & Tingkat Peran Penyuluh Pertanian \\
\hline 1. & $3,0-5,4$ & Sangat Tidak Baik \\
2. & $5,5-7,9$ & Tidak Baik \\
3. & $8,0-10,4$ & Kurang Baik \\
4. & $10,5-12,9$ & Baik \\
5. & $13,0-15,4$ & Sangat Baik \\
\hline
\end{tabular}

Sementara itu, analisis regresi dilakukan untuk mengetahui pengaruh kinerja peran penyuluh pertanian terhadap tingkat produksi usahatani jagung dengan menggunakan aplikasi STATA versi 14. Sebelum data diolah menggunakan regresi, dilakukan pengujian data terlebih dahulu yaitu uji asumsi klasik untuk memenuhi persyaratan Best Linear Unbiased Estimator (BLUE) antara lain uji normalitas, uji heteroskedastisitas dan uji multikolinearitas. Untuk menganalisis pengaruh kinerja peran penyuluh pertanian terhadap tingkat produksi usahatani jagung digunakan analisis regresi linear berganda dengan persamaan sebagai berikut: 


$$
Y=\alpha+\beta_{1} X_{1}+\beta_{2} X_{2}+\beta_{3} X_{3}+\beta_{4} X_{4}+\beta_{5} X_{5}+\beta_{6} X_{6}+\varepsilon
$$

Keterangan:

$\mathrm{Y}=$ Produksi Usahatani Jagung $(\mathrm{kg}) ; \alpha=$ Nilai konstanta (intersept); $\beta=$ Koefisien arah regresi $($ slope $) ; \mathrm{X}_{1}=$ Luas lahan (hektar); $\mathrm{X}_{2}=$ Jumlah benih (kg); $\mathrm{X}_{3}=$ Jumlah pupuk (kg); $\mathrm{X}_{4}=$ Jumlah pestisida (liter); $\mathrm{X}_{5}=$ Jumlah tenaga kerja (orang); $\mathrm{X}_{6}$ $=$ Peran penyuluh pertanian (skor); $\varepsilon=$ Error

\section{HASIL DAN PEMBAHASAN}

\section{Karakteristik Petani dan Usahatani Jagung}

Karakteristik dalam penelitian ini terdiri dari jenis kelamin, usia, tingkat pendidikan formal, pengalaman usahatani, jumlah tanggungan keluarga, luas lahan dan jumlah produksi jagung. Deskripsi dari masingmasing karakteristik petani dijelaskan lebih lanjut pada Tabel 3.

Tabel 3. Karakteristik Petani dan Usahatani Jagung di Desa Nunuk Baru

\begin{tabular}{lccc}
\hline \multicolumn{1}{c}{ Karakteristik Petani } & Kategori & Jumlah (orang) & Persentase (\%) \\
\hline Jenis Kelamin & Laki-laki & 71 & 88,75 \\
& Perempuan & 9 & 11,25 \\
\hline \multirow{2}{*}{ Usia (tahun) } & $15-49$ & 36 & 45 \\
& $50-64$ & 32 & 40 \\
& $>64$ & 12 & 15 \\
Tingkat Pendidikan Formal & Tidak Tamat SD & 3 & 3,75 \\
(tahun) & SD & 65 & 81,25 \\
& SMP & 5 & 6,25 \\
& SMA & 6 & 7,5 \\
Pengalaman Usahatani (tahun) & Perguruan Tinggi & 1 & 1,25 \\
& $1-14$ & 15 & 18,75 \\
& $15-25$ & 34 & 42,5 \\
Jumlah Tanggungan Keluarga & $>26$ & 31 & 38,75 \\
(orang) & $0-3$ & 38 & 47,5 \\
& $4-7$ & 41 & 51,25 \\
Luas Lahan (Ha) & $8-13$ & 1 & 1,25 \\
& $<0,5 \mathrm{ha}$ & 19 & 23,75 \\
& 0,5 ha -1 ha & 45 & 56,25 \\
& $>1$ ha & 16 & 20 \\
Produksi Jagung (Kg) & & & \\
\hline
\end{tabular}

Berdasarkan Tabel 3, jenis kelamin responden ini didominasi oleh jenis kelamin laki-laki dengan jumlah 71 orang atau $88,75 \%$ dari total responden. Sementara itu, responden berjenis kelamin perempuan berjumlah 8 orang atau $11,25 \%$ dari total responden. Hal tersebut menunjukkan bahwa jenis kelamin mempengaruhi keputusan individu dalam melakukan pekerjaan. Jenis kelamin laki-laki lebih banyak dibutuhkan pada saat persiapan lahan dan pengangkutan hasil panen karena saat proses tersebut dibutuhkan kemampuan fisik yang lebih kuat. Sementara itu, jenis kelamin perempuan lebih banyak dibutuhkan pada saat proses penanaman dan pemeliharaan. Usia responden dalam penelitian ini terbanyak berada di usia 15 - 49 tahun yaitu sebanyak 36 orang atau $45 \%$, untuk usia 50 - 64 tahun sebanyak 32 orang atau $40 \%$, dan usia 64 tahun sebanyak 12 orang atau 15\%. Hal tersebut menunjukkan bahwa sebagian besar responden berada pada kategori usia produktif. Usia terendah responden adalah 21 tahun sedangkan usia tertinggi adalah 75 tahun dan rata-rata usianya adalah 50 tahun.

Tingkat pendidikan responden dalam penelitian ini responden terbanyak ada ditingkat pendidikan SD yaitu sebanyak 65 orang atau $81,25 \%$ dari total responden. Hal ini menunjukkan bahwa tingkat pendidikan petani jagung di Desa Nunuk Baru yang menjadi responden penelitian sebagian besar masih 
tergolong rendah. Keadaan ini disebabkan rendahnya kesadaran orang tua jaman dahulu untuk menyekolahkan anaknya ke jenjang yang lebih tinggi dan kondisi perekonomian keluarga yang rendah. Pengalaman usahatani responden yang paling lama adalah 50 tahun dan terbaru adalah 2 tahun, persentase terbesar berada pada umur 15-25 tahun yaitu sebanyak 34 orang atau 42,5\% dari total responden. Menurut Mardikanto (1993) petani yang sudah lama berusahatani akan lebih mudah menerapkan inovasi daripada petani pemula, hal ini dikarenakan pengalaman yang lebih banyak sehingga sudah dapat membuat perbandingan dalam mengambil keputusan.

Jumlah tanggungan keluarga responden dalam penelitian ini paling banyak berjumlah antara 4-7 orang dengan persentase sebesar $41 \%$. Jumlah tanggungan keluarga berada pada kategori sedikit adalah tidak memiliki tanggungan keluarga dan jumlah tanggungan keluarga terbanyak berjumlah 8 orang. Luas lahan responden berkisar antara 2,25 Ha hingga 0,2 Ha. Responden yang memiliki luas lahan <0,5 Ha terdapat sebanyak 19 orang atau $23,75 \%$ dari total responden, luas lahan $0,5-1,0$ Ha sebanyak 45 orang atau 56,25 dari total responden, dan luas lahan $>1,0$ Ha sebanyak 16 orang atau 20\% dari total responden. Hal tersebut menunjukkan bahwa mayoritas responden tergolong ke dalam kategori petani skala menengah. Jumlah produksi jagung yang dihasilkan oleh responden dalam penelitian ini berkisar antara $800 \mathrm{~kg}$ hingga $15.000 \mathrm{~kg}$ dengan rata-rata sebesar $4.768,75 \mathrm{~kg}$. Persentase produksi jagung terbanyak berada pada kisaran $1.000 \mathrm{~kg}-5.000 \mathrm{~kg}$ yaitu sebesar $68,75 \%$ dari total responden.

\section{Peran Penyuluh Pertanian}

Petani sebagai pelaku utama dalam kegiatan usahataninya yang merupakan modal utama penggerak pembangunan pertanian di Indonesia. Oleh karena itu, kualitas sumber daya manusia petani perlu ditingkatkan melalui penyuluhan pertanian yang didampingi oleh seorang penyuluh. Menurut Rahmawati et al. (2019), kinerja penyuluh pertanian dianggap baik, jika dapat memfasilitasi petani dalam proses usahatani, pengelolaan pasca panen sampai penyerapan produk akhir oleh pasar. Peran penyuluh dalam penelitian ini dilihat dari 7 aspek yakni motivator, edukator, katalisator, komunikator, konsultan, fasilitator dan organisator. Penilaian petani terhadap peran penyuluh pertanian di Desa Nunuk Baru yang dilihat dari ketujuh aspek tersebut dapat dilihat pada Tabel 4.

Tabel 4. Peran Penyuluh Pertanian di Desa Nunuk Baru

\begin{tabular}{lcccc}
\hline Peran Penyuluh & Interval Kelas & Jumlah (orang) & Persentase (\%) & Tingkat Peranan \\
\hline \multirow{4}{*}{ Motivator } & $3,0-5,4$ & 0 & 0 & Sangat Tidak Baik \\
& $5,5-7,9$ & 0 & 0 & Tidak Baik \\
& $8,0-10,4$ & 4 & 5 & Kurang Baik \\
& $\mathbf{1 0 , 5}-\mathbf{1 2 , 9}$ & $\mathbf{4 3}$ & $\mathbf{5 3 , 7 5}$ & Baik \\
& $13,0-15,4$ & 33 & 41,25 & Sangat Baik \\
\hline \multirow{4}{*}{ Edukator } & $3,0-5,4$ & 0 & 0 & Sangat Tidak Baik \\
& $5,5-7,9$ & 0 & 0 & Tidak Baik \\
& $8,0-10,4$ & 4 & 5 & Kurang Baik \\
& $\mathbf{1 0 , 5}-\mathbf{1 2 , 9}$ & $\mathbf{4 0}$ & $\mathbf{5 0}$ & Baik \\
& $13,0-15,4$ & 36 & 45 & Sangat Baik \\
\hline \multirow{4}{*}{ Katalisator } & $3,0-5,4$ & 0 & 0 & Sangat Tidak Baik \\
& $5,5-7,9$ & 0 & 0 & Tidak Baik \\
& $8,0-10,4$ & 1 & 1,25 & Kurang Baik \\
& $10,5-12,9$ & 34 & 42,5 & Baik \\
& $\mathbf{1 3 , 0}-\mathbf{1 5 , 4}$ & $\mathbf{4 5}$ & $\mathbf{5 6 , 2 5}$ & Sangat Baik \\
\hline \multirow{5}{*}{ Komunikator } & $3,0-5,4$ & 0 & 0 & Sangat Tidak Baik \\
& $5,5-7,9$ & 0 & 0 & Tidak Baik \\
& $8,0-10,4$ & 2 & 2,5 & Kurang Baik \\
& $\mathbf{1 0 , 5}-\mathbf{1 2 , 9}$ & $\mathbf{3 9}$ & $\mathbf{4 8 , 7 5}$ & Baik \\
& $\mathbf{1 3 , 0}-\mathbf{1 5 , 4}$ & $\mathbf{3 9}$ & $\mathbf{4 8 , 7 5}$ & Sangat Baik \\
\hline \multirow{4}{*}{ Konsultan } & $3,0-5,4$ & 0 & 0 & Sangat Tidak Baik \\
& $5,5-7,9$ & 0 & 0 & Tidak Baik \\
& $8,0-10,4$ & 2 & 2,5 & Kurang Baik \\
& $10,5-12,9$ & 27 & 33,75 & Baik
\end{tabular}




\begin{tabular}{lcccc} 
& $\mathbf{1 3 , 0}-\mathbf{1 5 , 4}$ & $\mathbf{5 1}$ & $\mathbf{6 3 , 7 5}$ & Sangat Baik \\
\hline \multirow{4}{*}{ Fasilitator } & $3,0-5,4$ & 0 & 0 & Sangat Tidak Baik \\
& $5,5-7,9$ & 1 & 1,25 & Tidak Baik \\
& $8,0-10,4$ & 32 & 40 & Kurang Baik \\
& $\mathbf{1 0 , 5}-\mathbf{1 2 , 9}$ & $\mathbf{3 5}$ & $\mathbf{4 3 , 7 5}$ & Baik \\
& $13,0-15,4$ & 12 & 15 & Sangat Baik \\
\hline \multirow{4}{*}{ Organisator } & $3,0-5,4$ & 0 & 0 & Sangat Tidak Baik \\
& $5,5-7,9$ & 0 & 0 & Tidak Baik \\
& $8,0-10,4$ & 0 & 1,25 & Kurang Baik \\
& $10,5-12,9$ & 20 & 25 & Baik \\
& $\mathbf{1 3 , 0}-\mathbf{1 5 , 4}$ & $\mathbf{5 9}$ & $\mathbf{7 3 , 7 5}$ & Sangat Baik \\
\hline
\end{tabular}

Tabel 4 memperlihatkan bahwa terdapat 4 aspek utama peran penyuluh pertanian dari 7 aspek yang memperlihatkan bahwa persepsi petani terhadap peran penyuluh dinilai sangat baik. Keempat indikator tersebut antara lain katalisator, komunikator, konsultan dan organisator. Sebagian besar penilaian petani jagung terhadap peran penyuluh pertanian sebagai motivator adalah baik, yaitu sebanyak 43 responden atau $53,74 \%$ dari total responden. Hal ini sesuai dengan penelitian Haryanto et al., (2017) peran penyuluh sebagai motivator yaitu berperan untuk mempengaruhi, memberi semangat dan mendorong petani agar mereka mau melakukan perubahan ke arah yang lebih baik. Dalam penelitian ini terdapat tiga indikator yang dinilai dari peran penyuluh sebagai motivator, yaitu membantu petani mengarahkan usahatani, mendorong untuk mengembangkan usahatani dan mendorong untuk menerapkan teknologi dalam usahatani. Menurut petani Desa Nunuk Baru, penyuluh telah mengarahkan petani untuk menjalankan usahataninya sesuai dengan anjuran Dinas Pertanian serta mendorong petani untuk menerapkan teknologi pada usahataninya. Penyuluh pertanian juga memberikan informasi-informasi kepada petani untuk mengembangkan usahatani yang lebih menguntungkan serta memotivasi petani untuk meningkatkan hasil produksi jagung serta mempraktikkan alat teknologi untuk meningkatkan hasil produksi usahatani.

Namun menurut petani dan tenaga penyuluh, teknologi yang digunakan dalam usahatani jagung masih belum banyak inovasi dan variasinya, sehingga teknologi yang diterapkan oleh petani belum mampu membantu petani untuk meningkatkan hasil produksi jagung. Teknologi pertanian yang digunakan untuk komoditas jagung hanya sebatas untuk membantu petani dalam kegiatan pasca panennya yaitu mesin pemipil jagung. Hal ini sejalan dengan penelitian yang dilakukan oleh Rahmawati et al. (2019) yang menyimpulkan bahwa peran kinerja penyuluh pertanian sangat baik dalam memotivasi petani dalam mengakses informasi intensifikasi jagung, mengarahkan usahatani sesuai program intensifikasi jagung, dan memotivasi petani meningkatkan hasil produksi tanaman jagung. Menurut Faqih (2014), peran penyuluh pertanian sebagai motivator diharapkan dapat mempengaruhi dan membangkitkan semangat petani sehingga petani tergerak untuk berpartisipasi dalam kegiatan usahatani.

Penilaian mayoritas petani jagung terhadap peran penyuluh pertanian sebagai edukator adalah baik, yaitu sebanyak 40 responden atau 50\% dari total responden. Peran penyuluh sebagai edukator terdiri dari tiga indikator, yaitu meningkatkan pengetahuan, melatih keterampilan dan memberikan pelatihan. Berdasarkan hasil wawancara, penyuluh telah menambah pengetahuan petani dalam mengelola usahatani yang tepat. Hal ini dibuktikan dari pengetahuan berupa informasi cara mengelola usahatani jagung yang tepat dan menguntungkan mulai dari penggunaan input hingga panen yang diperoleh petani setiap kurang lebih 2 kali dalam sebulan dari diskusi bersama penyuluh. Penelitian Lukuyu et al., (2012) menyatakan bahwa, cara paling penting untuk menyebarkan teknologi baru adalah melalui kunjungan pertanian seperti pertemuan kelompok rutin yang diselenggarakan di demplot dan studi banding ke desa lain yang sukses dalam adopsi teknologi.

Peran penyuluh sebagai edukator yang lainnya adalah memberikan pelatihan tentang cara mengendalikan hama penyakit tanaman seperti cara menggunakan obat-obatan yang tepat dan sesuai dengan dosis serta membimbing petani dalam menggunakan benih bantuan varietas baru yang diberikan oleh pemerintah. Petani juga mendapatkan pelatihan dalam menggunakan teknologi baru dengan cara mendemonstrasikan. Pada komoditas jagung, pelatihan teknologi yang didapatkan oleh petani belum 
bervariasi, yaitu mesin pemipil jagung. Hal ini sejalan dengan penelitian yang dilakukan oleh Rahmawati et al. (2019) yang menyimpulkan bahwa kinerja penyuluh pertanian berperan sangat baik dalam meningkatkan pengetahuan petani terhadap ide baru serta menyusun materi, media dan metode penyuluhan yang sesuai dengan program intensifikasi jagung. Peran kinerja penyuluh pertanian dalam penelitian Rahmawati et al. (2019) menyatakan kurang baik dalam memberikan pelatihan menggunakan teknologi kepada petani.

Menurut Syahyuti (2014), fungsi utama penyuluh adalah sebagai mata rantai (change agent linkage) antara pemerintah (change agency) dengan masyarakat (client system). Penyuluh merupakan tokoh penghubung yang kokoh dan seimbang dalam menjembatani program pemerintah dan kepentingan petani. Dalam hal ini penyuluh memiliki peran sebagai katalisator bagi petani. Penilaian mayoritas petani jagung terhadap peran penyuluh pertanian sebagai katalisator adalah sangat baik, yaitu sebanyak 45 responden atau 56,25\% dari total responden. Peran penyuluh sebagai katalisator terdiri dari tiga indikator, yaitu menyampaikan aspirasi petani, menyampaikan kebijakan sektor pertanian kepada petani dan menjadi penghubung antara petani dengan lembaga pemerintah.

Menurut petani Desa Nunuk Baru, penyuluh telah menyampaikan aspirasi petani kepada pemerintah khususnya Dinas Pertanian. Aspirasi petani tersebut biasanya berupa kebutuhan petani terhadap benih dan pupuk subsidi. Hal tersebut juga dapat dilihat dari peran penyuluh yang membantu petani menghubungkan petani dengan dinas pertanian seperti bantuan rutin setiap tahun seperti benih jagung dan alat mesin pertanian. Petugas penyuluh bertugas dalam mendata penerima bantuan dan menyalurkan kepada petani. Penyuluh juga menyampaikan informasi, peraturan dan kebijakan di bidang pertanian kepada petani. Menurut Padillah et al. (2018), peranan penyuluh didalam suatu program sangat berperan penting guna sebagai jembatan penghubung antara pemerintah serta menyampaikan umpan balik dari masyarakat yang bertujuan membantu masyarakat memperbaiki mutu hidup dan kesejahteraannya. Hasil penelitian ini sejalan dengan penelitian Putri \& Safitri (2018) yang menyatakan bahwa penyuluh berperan sebagai penghubung antara petani dengan balai penelitian tanaman pangan dalam memberikan informasi kepada petani mengenai inovasi-inovasi baru untuk meningkatkan hasil produksi pertanian.

Penilaian mayoritas petani jagung terhadap peran penyuluh pertanian sebagai komunikator adalah baik cenderung sangat baik, yaitu penilaian petani paling banyak berada pada kategori baik dan sangat baik, yaitu sama-sama sebanyak 39 responden atau $48,75 \%$ dari total responden. Peran penyuluh sebagai komunikator terdiri dari tiga indikator, yaitu kemampuan berkomunikasi yang baik, membantu mempercepat arus informasi dan membantu mengambil keputusan. Hal tersebut dibuktikan bahwa komunikasi penyuluh kepada petani sudah menggunakan bahasa yang baik dan mudah dipahami. Penyuluh juga telah membantu petani dalam menyampaikan informasi-informasi usahatani jagung dan juga membantu menyelesaikan masalah kemudian mengambil keputusan secara bersama-sama. Hal ini sejalan dengan penelitian Zulfikar et al. (2018), petani mampu menyerap dengan baik setiap materi yang disampaikan oleh penyuluh. Apabila ada hal yang belum dipahami petani sangat aktif dalam menggali informasi dengan penyuluh karena adanya diskusi dalam setiap pertemuan. Penelitian lainnya yang dilakukan oleh Rahmawati et al. (2019) menyatakan bahwa penyuluh pertanian di Kabupaten Gorontalo Utara berperan sangat baik dalam membantu komunikasi antara petani dengan stakeholder terkait dan mempercepat arus informasi petani. Menurut Syahyuti (2014) dibutuhkan tenaga penyuluh yang memiliki kemampuan mengembangkan komunikasi partisipatif dan mampu membangun jaringan atau hubungan interaktif antara petani dengan pemerintah maupun swasta.

Penilaian mayoritas petani jagung terhadap peran penyuluh pertanian sebagai konsultan adalah sangat baik, yaitu sebanyak 51 responden atau $63,75 \%$ dari total responden. Peran penyuluh sebagai konsultan terdiri dari tiga indikator, yaitu sebagai penasihat, membantu memecahkan masalah dan memberikan informasi usahatani yang unggul. Berdasarkan hasil wawancara dengan petani, penyuluh telah memberikan nasihat kepada petani apabila usahatani yang dilakukan oleh petani masih kurang tepat dan kurang memberikan keuntungan yang maksimal. Selain itu, penyuluh membantu petani memecahkan masalah yang berkaitan dengan usahatani jagung serta memberikan informasi kepada petani mengenai keunggulan dan keuntungan usahatani yang cocok dan sesuai dengan kondisi musim, tanah dan hama di daerah penelitian. Hal ini sejalan dengan penelitian Sadono (2008), penyuluhan pertanian mempunyai

Jurnal Penyuluhan | Vol. 17 (02) 2021 | 120 
peran untuk membantu petani agar dapat menolong dirinya untuk mengatasi permasalahan yang dihadapinya secara baik dan memuaskan sehingga meningkat derajat kehidupannya. Penelitian Famili et al. (2017) menyatakan bahwa, penyuluh melakukan konsultasi terhadap kelompok tani secara bersama-sama untuk mencari jalan keluar dari kendala yang dihadapi oleh petani.

Peran penyuluh sebagai fasilitator adalah memfasilitasi petani dengan pihak lain yang mendukung kemajuan dan perbaikan usahatani seperti lembaga penelitian, pengusaha (pemasaran) dan permodalan (Haryanto et al., 2017). Penilaian mayoritas petani jagung terhadap peran penyuluh pertanian sebagai fasilitator adalah baik, yaitu sebanyak 35 responden atau $43,75 \%$ dari total responden. Peran penyuluh sebagai fasilitator terdiri dari tiga indikator, yaitu memfasilitasi kegiatan belajar mengajar, akses petani kepada pihak permodalan dan akses pasar. Berdasarkan hasil wawancara dengan petani, penyuluh pertanian telah memfasilitasi petani dalam kegiatan penyuluhan seperti memberikan pembelajaran tentang usahatani dan menggerakkan petani untuk melakukan perubahan dalam berusahatani yang lebih maju. Penyuluh pertanian juga telah menginformasikan serta menghubungkan petani dengan programprogram permodalan dari pemerintah dan bank swasta.

Peran penyuluh dalam memfasilitasi petani untuk mengakses pasar berdasarkan penilaian petani masih kurang baik. Hal ini dikarenakan penyuluh pertanian belum mampu memutus mata rantai tengkulak/bandar desa dan belum menghubungkan dengan perusahaan bidang agribisnis. Penyuluh di Desa Nunuk hanya mampu menjadi pionir penggerak untuk menampung hasil pertanian di kelompok tani dan memasarkannya secara kolektif. Hasil penelitian ini sejalan dengan penelitian Listiana et al. (2018), penyuluh telah memiliki kemampuan memfasilitasi; mengupayakan kemudahan akses sumber informasi, teknologi dan sumber daya lainnya, secara umum tingkat kemampuan penyuluh dalam memfasilitasi berada pada kategori sedang cenderung rendah. Menurut Saputri et al. (2016), peran penyuluh sebagai fasilitator merupakan dasar peningkatan kapasitas petani dengan cara meningkatkan pengetahuan, keterampilan dan sikap petani dalam berusahatani.

Penilaian mayoritas petani jagung terhadap peran penyuluh pertanian sebagai organisator adalah sangat baik, yaitu sebanyak 59 responden atau $73,75 \%$ dari total responden. Peran penyuluh sebagai organisator terdiri dari tiga indikator, yaitu mengkordinir kegiatan usahatani agar lebih terarah, menumbuhkan wahana kerja sama petani dan mengarahkan petani dalam memilih usaha yang lebih menguntungkan. Hal tersebut dibuktikan bahwa, penyuluh membantu petani dalam mengarahkan usahatani yang baik dan tepat mulai dari penggunaan sarana produksi pertanian (saprotan) hingga panen. Kegiatan penyuluhan membantu petani dalam membangun wahana kerja sama antar petani dalam kelompok tani. Penyuluh juga membantu petani dalam merencanakan komoditas apa yang sesuai dengan musim agar menghindari resiko gagal panen. Hasil penelitian ini tidak sejalan dengan penelitian Listiana et al. (2018), kemampuan penyuluh dalam mengembangkan organisasi belum optimal masih dalam kategori sedang. Penelitian Haryanto et al. (2017) menyatakan bahwa penyuluh sebagai penganalisis lingkungan berperan dalam membantu petani menganalisis usahatani, mengatasi masalah yang dihadapi petani serta menganalisis situasi dan masalah dalam menyusun program penyuluhan.

\section{Analisis Faktor-faktor yang Mempengaruhi Produksi Usahatani Jagung}

Produksi usahatani dipengaruhi oleh faktor internal dan eksternal. Faktor-faktor produksi usahatani jagung yang diidentifikasi sebagai variabel dalam penelitian ini yaitu luas lahan, benih, pupuk, pestisida, tenaga kerja sebagai faktor internal dan peran penyuluh pertanian sebagai faktor eksternal. Berdasarkan hasil analisis regresi berganda didapatkan hasil seperti terlihat pada Tabel 5 berikut. 
Tabel 5. Hasil Analisis Regresi Linear Berganda Faktor-Faktor Produksi Usahatani Jagung di Desa Nunuk Baru, Kecamatan Maja, Kabupaten Majalengka

\begin{tabular}{lcccc}
\hline \multicolumn{1}{c}{ Variabel } & Koefisien Regresi & Standar Error & t-hitung & p-value \\
\hline Luas Lahan $\left(\mathrm{X}_{1}\right)$ & 4341,19 & 402,0382 & 10,80 & $0,000^{* *}$ \\
Benih $\left(\mathrm{X}_{2}\right)$ & 106,2147 & 41,33998 & 2,57 & $0,012^{*}$ \\
Pupuk $\left(\mathrm{X}_{3}\right)$ & $-0,0392993$ & 0,2674048 & $-0,15$ & $0,884^{\text {ns }}$ \\
Pestisida $\left(\mathrm{X}_{4}\right)$ & 85,61136 & 70,56789 & 1,21 & $0,229^{\text {ns }}$ \\
Tenaga Kerja $\left(\mathrm{X}_{5}\right)$ & 4,715171 & 7,25763 & 0,65 & $0,518^{\text {ns }}$ \\
Peran Penyuluh Pertanian $\left(\mathrm{X}_{6}\right)$ & $-17,90352$ & 21,4898 & $-0,83$ & $0,407^{\text {ns }}$ \\
Konstanta & 1045,636 & 1896,74 & 0,55 & 0,583 \\
F Hitung & & & & 92,33 \\
Sigh F & & & & 0,0000 \\
Adjusted R2 & & & & 0,8740 \\
N & & & & 80 \\
\hline
\end{tabular}

Keterangan $: *=$ signifikan pada taraf 0,$01 ; * *=$ signifikan pada taraf 0,$5 ; \mathrm{ns}=$ tidak signifikan

Berdasarkan hasil analisis pada Tabel 5 diperoleh persamaan regresi hasil penelitian adalah $\mathrm{Y}=1045,636+4.341,19 \mathrm{X}_{1}+106,214 \mathrm{X}_{2}-0,039 \mathrm{X}_{3}+85,611 \mathrm{X}_{4}+4,715 \mathrm{X}_{5}-17,903 \mathrm{X}_{6}+\varepsilon$. Nilai signifikansi $\mathrm{F}(0,0000)<0,05$, maka $\mathrm{H} 0$ dan $\mathrm{H} 1$ diterima, artinya variabel bebas secara bersama-sama berpengaruh signifikan terhadap variabel terikat (produksi jagung). Nilai koefisien konstanta sebesar 1045,636 menunjukkan bahwa apabila variabel input produksi (luas lahan, jumlah benih, jumlah pupuk, jumlah pestisida, jumlah tenaga kerja dan peran penyuluh pertanian) nilainya 0 atau konstan, maka produksi jagung akan positif 1045,636. Secara parsial, variabel yang berpengaruh terhadap produksi jagung di Desa Nunuk Baru adalah luas lahan dan jumlah benih.

Luas lahan berpengaruh positif dengan tingkat signifikansi sebesar 0,01 dan nilai koefisien sebesar $4.341,19$, artinya setiap peningkatan luas lahan sebesar $1 \%$ dengan menganggap faktor lainnya tetap (ceteris paribus) maka jumlah produksi jagung akan mengalami peningkatan sebesar 4.341,19. Hasil penelitian ini sejalan dengan hasil penelitian Tomy (2013) tentang faktor-faktor yang mempengaruhi produksi usahatani jagung di Kecamatan Sindue Kabupaten Donggala yang menyatakan bahwa terdapat lahan potensial yang dapat digunakan untuk pertanaman jagung, sehingga penambahan luas lahan untuk peningkatan produksi masih dapat dilakukan. Penelitian lainnya yang dilakukan oleh Mikail (2018) juga menyatakan luas lahan berpengaruh positif terhadap produksi jagung di Desa Benteng.

Jumlah benih berpengaruh positif dengan tingkat signifikansi sebesar 0,5 dan nilai koefisien sebesar 106,21 , artinya setiap peningkatan jumlah benih sebesar $1 \%$ dengan menganggap faktor lainnya tetap (ceteris paribus) maka jumlah produksi jagung akan mengalami peningkatan sebesar 106,21. Hal ini sesuai dengan penelitian jagung yang dilakukan oleh Agustian (2015) tentang analisis faktor-faktor yang mempengaruhi produksi pada usahatani jagung di Kabupaten Garut yang menyatakan bahwa penggunaan benih jagung berpengaruh nyata dan berhubungan positif terhadap produksi jagung.

Peran penyuluh pertanian tidak berpegaruh terhadap produksi petani jagung. Berdasarkan hasil wawancara dengan petani responden, secara keseluruhan peran penyuluh pertanian sudah baik dalam menjalankan tugasnya pada kegiatan penyuluhan namun hal tersebut tidak berdampak nyata terhadap produksi usahatani jagung. Hasil penelitian ini sejalan dengan penelitian Saridewi \& Siregar (2020), yang menyatakan bahwa peran penyuluh di Kabupaten Tasikmalaya tidak berpengaruh terhadap peningkatan produksi padi. Dalam penelitian tersebut peran penyuluh dibagi menjadi lima, yaitu penasehat, teknisi, penghubung, organisatoris dan agen pembaharu. Berbeda dengan hasil penelitian Sundari et al., (2015) tentang peran penyuluh pertanian terhadap peningkatan produksi usahatani di Kabupaten Pontianak yang menyatakan bahwa penyuluh pertanian cukup berperan terhadap peningkatan produksi usahatani padi di Kabupaten Pontianak.

Penyuluh pertanian di Desa Nunuk Baru melakukan kunjungan rutin minimal satu bulan sekali ke tiap kelompok tani. Kunjungan tersebut berupa kegiatan diskusi tentang usahatani seperti penggunaan sarana input (benih, pupuk dan pestisida), penggunaan alat mesin pertanian dan permasalahan yang dihadapi 
petani. Namun arahan yang diberikan oleh penyuluh sering kali tidak diterapkan oleh petani, petani tersebut masih cenderung melakukan kebiasaan-kebiasaannya sendiri dalam mengelola usahatani jagung sehingga produksi jagung masih kurang maksimal. Hal ini diperkuat dengan pernyataan petugas penyuluh pertanian di Desa Nunuk Baru yang menyatakan bahwa sulit untuk mengubah kebiasaan petani dalam mengelola usahataninya. Sebagian besar petani tidak mau menerapkan apa yang telah diarahkan oleh penyuluh dikarenakan mereka takut mengalami kegagalan atau kerugian sehingga diperlukannya bukti nyata untuk memotivasi petani. Pernyataan tersebut membuktikan bahwa transfer informasi antar petani dengan penyuluh belum berjalan dengan lancar karena petani kurang percaya dengan penyuluh.

Kurangnya tingkat kepercayaan petani terhadap penyuluh harus diatasi untuk mensukseskan keberhasilan tugas penyuluh dalam membantu petani meningkatkan produksi usahatani jagung. Menurut Prayoga et al. (2019), untuk meningkatkan kepercayaan antara petani dengan tenaga penyuluh dapat dilakukan dengan melibatkan aktor informal. Aktor informal yang dimaksud adalah tokoh masyarakat seperti ketua kelompok tani atau orang yang dituakan oleh masyarakat petani agar lebih menumbukan kepercayaan petani. Tokoh masyarakat merupakan strategi untuk membentuk kepercayaan petani karena petani akan menaruh rasa kepercayaan setelah melihat orang yang mereka percayai bekerja sama dengan tenaga penyuluh sehingga akan memperlancar proses transfer informasi yang disampaikan oleh penyuluh.

\section{KESIMPULAN}

Berdasarkan hasil penelitian yang telah dilakukan, dapat disimpulkan bahwa: (1) Peran penyuluh pertanian bagi petani jagung dikategorikan sangat baik dalam menjalankan tugasnya sebagai katalisator, komunikator, konsultan dan organisator. Sedangkan penilaian petani terhadap peran penyuluh pertanian sebagai motivator, edukator dan fasilitator dikategorikan baik. Dilihat dari 7 aspek peran penyuluh pada penelitian ini sudah mewakili peran penyuluh dalam kegiatan penyuluhan pertanian. Peran penyuluh sebagai motivator, edukator dan fasilitator masih perlu ditingkatkan lagi. (2) Variabel luas lahan dan jumlah benih berpengaruh terhadap produksi jagung. Sedangkan Variabel peran penyuluh pertanian tidak berpengaruh terhadap produksi usahatani jagung. Salah satu faktor yang menyebabkan tidak signifikannya peran penyuluh terhadap produksi jagung adalah petani yang tidak menerapkan apa yang sudah diberikan oleh penyuluh dan masih melakukan kebiasaan-kebiasaannya sendiri dalam mengelola usahatani jagung sehingga produksi jagung kurang masih kurang maksimal.

\section{UCAPAN TERIMA KASIH}

Ucapan terima kasih penulis sampaikan kepada pihak pemberi dana penelitian yaitu Hibah Riset Internal Universitas Padjadjaran tahun anggaran 2020 dengan no. 1427/UN6.3.1/LT/2020. Penulis juga menyampaikan terima kasih pada Fakultas Pertanian Universitas Padjadjaran khususnya Program Studi Agribisnis dan juga kepada seluruh pihak yang turut membantu dalam melaksanakan penelitian ini.

\section{DAFTAR PUSTAKA}

Agustian, A. (2015). Analisis Faktor-faktor yang Mempengaruhi Produksi pada Usahtani Kagung di Kabupaten Garut, Provinsi Jawa Barat, Indonesi. Pusat Sosial Ekonomi Dan Kebijakan Pertanian, Badan Penelitian Dan Pengembangan Pertanian:Bogor.

Apriani, A. E., Soetoro, \& Nurdin, Y. M. (2016). Analisis Usahatani Jagung (Zea Mays L) (Suatu kasus di Desa Pancawangi Kecamatan Pancatengah Kabupaten Tasikmalaya). Jurnal Ilmiah Mahasiswa Agroinfo Galuh, 2(3), 145-150.

Ardita, DWP, S., \& Widjanarko, D. (2017). Kinerja Penyuluh Pertanian Menurut Persepsi Petani: Studi Kasus di Kabupaten Landak. Journal of Vocational and Career Education, 2(1), 1-8.

Badan Pusat Statistik Kabupaten Majalengka. (2018). Luas Panen, Produksi dan Produktivitas Tanaman Pangan dan Palawija Tahun 2017. Badan Pusat Statistik Kabupaten Majalengka.

Famili, R., Marijono, \& Imsiyah, N. (2017). Peran Penyuluh Pertanian Terhadap Keberdayaan 
Kelompok Tani Di Desa Tegalharjo Kecamatan Glenmore Kabupaten Banyuwangi. Jurnal Pendidikan Luar Sekolah, 1(2), 24-26.

Faqih, A. (2014). Peranan Penyuluh Pertanian Lapangan (PPL) dalam Kegiatan Pemberdayaan Kelompok terhadap Kinerja Kelompok Tani. Jurnal Agrijati, 26(1), 41-60.

Haryanto, Y., Sumardjo, Amanah, S., \& Tjitropranoto, P. (2017). Efektivitas Peran Penyuluh Swadaya dalam Pemberdayaan Petani di Provinsi Jawa Barat. Jurnal Pengkajian Dan Pengembangan Teknologi Pertanian, 20(2), 141-154.

Hernalius, L. A., Sumardjo, \& Hamzah, H. (2018). Pengaruh Penyuluhan Pertanian terhadap Tingkat Produktivitas Padi Sawah di Desa Bojongsari, Kecamatan Jampang Kulon, Kabupaten Sukabumi, Jawa Barat. Jurnal Sains Komunikasi Dan Pengembangan Masyarakat [JSKPM], 2(3), 279-288.

Kementerian Pertanian Republik Indonesia. (2018). Produksi Jagung Menurut Provinsi Tahun 20142018. Kementerian Pertanian Republik Indonesia.

Listiana, I., Sumardjo, Sadono, D., \& Tjiptopranoto, P. (2018). Hubungan Kapasitas Penyuluh dengan Kepuasan Petani. Jurnal Penyuluhan, 14(2), 244-256.

Lukuyu, B., Place, F., Franzel, S., \& Kiptot, E. (2012). Disseminating Improved Practices: Are Volunteer Farmer Trainers Effective? Journal of Agricultural Education and Extension, 18(5), $525-540$.

M, M., Syam, H., \& L, L. (2019). Peran Penyuluh Pertanian terhadap Peningkatan Kompetensi Petani dalam Aktivitas Kelompok Tani di Desa Rea Kecamatan Binuang Kabupaten Polewali Mandar. Universitas Negeri Makasar.

Mardikanto. (1993). Penyuluhan Pembangunan Pertanian. Sebelas Maret University: Surakarta.

Mikail. (2018). Faktor-Faktor Yang Mempengaruhi Produksi. Jurnal Ekonomi Pembangunan, 4(1), 47 58.

Muljono, P. (2007). Learning Society, Penyuluhan dan Pembangunan Bangsa. Jurnal Penyuluhan, 3(1), $55-62$.

Padillah, Purnaningsih, N., \& Sadono, D. (2018). Persepsi Petani tentang Peranan Penyuluh dalam Peningkatan Produksi Padidi Kecamatan Tabir Kabupaten Merangin Provinsi Jambi. Jurnal Penyuluhan, 14(1), 1-10.

Prayoga, K., Nurfadillah, S., Butar, I. B., \& Saragih, M. (2019). Membangun Kesalingpercayaan dalam Proses Transfer Informasi antara Petani dan Penyuluh Pertanian. Forum Penelitian Agro Ekonomi, 36(2), 143.

Putri, R. T., \& Safitri, R. (2018). Peran Penyuluh Pertanian Terhadap Penerapan Teknologi Tanam Jajar Legowo 2:1 (Kasus Kelompok Tani Gotong Royong 2 di Desa Klaseman, Kabupaten Probolinggo). Jurnal Ekonomi Pertanian Dan Agribisnis, 2(3), 167-178.

Rahmawati, Mahludin, B., \& Bahua, M. I. (2019). Peran Kinerja Penyuluh dan Efektivitas Pelaksanaan Penyuluhan pada Program Intensifikasi Jagung. Jurnal Sosial Ekonomi Pertanian, 15(1), 56-70.

Resicha, P. (2016). Peran Penyuluh Pertanian dalam Pengembangan Kelompok Tani di Nagari Sungai Pua Kecamatan Sungai Pua Kabupaten Agam. Universitas Andalas.

Sadono, D. (2008). Pemberdayaan Petani Paradigma Baru Penyuluhan Pertanian di Indonesia. Jurnal Penyuluhan, 4(1), 65-74.

Saputri, R. D., Anantanyu, S., \& Wijianto, A. (2016). Peran Penyuluh Pertanian Lapangan dengan Tingkat Perkembangan Kelompok Tani di Kabupaten Sukoharjo. Jurnal Arista, 4(3), 341-352.

Saridewi, T. R., \& Siregar, A. N. (2020). Hubungan antara peran penyuluh dan adopsi teknologi oleh 
petani terhadap peningkatan produksi padi di Kabupaten Tasikmalaya. Jurnal Penyuluhan Pertanian, 5(1), 55-61.

Simamora, B. (2005). Analisis Multivariat Pemasaran. Gramedia Utama. Jakarta.

Sundari, Yusra, A. H. A., \& Nurliza. (2015). Peran Penyuluh Pertanian terhadap Peningkatan Produksi Usahatani di Kabupaten Pontianak. Jurnal Social Economic of Agriculture, 4(1), 26-31.

Suryana, A., \& Agustian, A. (2018). Analisis Dayasaing Usahatani Jagung di Indonesia. Jurnal Analisis Kebijakan Pertanian, 12(2), 143-156.

Syahyuti. (2014). Peran Strategis Penyuluh Swadaya dalam Paradigma Baru Penyuluhan Pertanian di Indonesia. Forum Penelitian Agro Ekonomi, 32(1), 43-58.

Tomy, J. (2013). Faktor-faktor yang Mempengaruhi Produksi Usahatani Jagung di Kecamatan Sindue Kabupaten Donggala. In Jurnal Agroland (Vol. 17, Issue 3).

Zulfikar, Amanah, S., \& Asngari, P. S. (2018). Persepsi Petani terhadap Kompetensi Penyuluh Pertanian Tanaman Pangandi Kabupaten Aceh Utara. Jurnal Penyuluhan, 14(1), 159-174. 